\title{
Fuhrmanolepis beskydensis n.sp. (Cestoda: Dilepididae) from woodcock Scolopax rusticola L.(Aves, Charadriformes) in Slovakia with comments on sytematics and nomenclature of the genus Fuhrmanolepis Spassky et Spasskaya, 1965
}

\author{
J. K. MACKO, A. MACKOVÁ ${ }^{1}$, S. SABOLOVÁ-BARLÁKOVÁ
}

\begin{abstract}
Parasitological Institute of the Slovak Academy of Sciences, Hlinkova 3, 04001 Košice, Slovak Republic; ${ }^{1}$ Institute of Science, P. J. Šafárik University, Mánesova 23, 04154 Košice, Slovak Republic, E-mail: amacko@kosice.upjs.sk
\end{abstract}

\begin{abstract}
Summary
Fuhrmanolepis beskydensis n.sp. from woodcock, Scolopax rusticola L. in Slovakia is described based upon light microscope observation. The medium sized species possess a single crown of 21 'diorchid' (wrench-shaped) hooks, 28 $-30 \mu \mathrm{m}$ long. Irregularly alternating genital pores were combined with abnormal multiple shifting of pores within the lateral margins of strobila. Number of testes $18-25$. Cirrus-sac and evaginated cirrus are $115-135 \times 7-12$ and $26 \times 6-11 \mu \mathrm{m}$, respectively. The species is differentiated from closely related congeneric taxons and some other morphologically similar dilepidids. An attention is being paid to taxonomy and nomenclature of Fuhrmanolepis Spassky et Spaskaja, 1965 regarding an emendation of mentioned genus to Fuhrmannolepis by Bona (1994a) and modification of its diagnosis.
\end{abstract}

Key words: Cestoda; Dilepididae; Fuhrmanolepis, Fuhrmannolepis; nomenclature; taxonomy; Fuhrmanolepis beskydensis n.sp.; Scolopax rusticola; Charadriiformes; Slovakia

\section{Introduction}

Aploparaksidae and Dilepididae belong to most numerous tapeworm groups parasitizing in Scolopax rusticola L. in Slovakia. Faunistic survey carried out in an area near Bardejov revealed not only the common tapeworm species (Ryšavý \& Farkaš, 1982), but also other unknown taxons, such as Fuhrmanolepis beskydensis n.sp. Besides having dilepidid characteristics, this species displays alternating genital pores, combined with multiple abnormal shifting of the pores and changing their position within the lateral margins of the strobilae. Similar changing of genital pores has brought about formation of the genus Diagonaliporus Krotov, 1951 (Krotov, 1951). The species belonging to this group have then been transferred into other genera, including the Fuhrmanolepis Spassky et Spasskaya, 1965
(Schmidt, 1986; Spaskaya \& Spassky, 1978) or into the genus Fuhrmannolepis (sensu Bona, 1994a). In connection with placing the new species into the original genus Fuhrmanolepis this paper deals with several nomenclatural and taxonomical problems of the mentioned genera.

\section{Materials and methods}

Tapeworms were recovered from the woodcock Scolopax rusticola L., examined within the period of $1958-1970$ in Kurov near Bardejov, north eastern Slovakia. The specimens were fixed and preserved in alcohol-formaldehydeacetic acid, stained in Semichon's and Blazhin's acetic carmines, dehydrated in ethanol series, cleared in clove oil and mounted into Canada balsam. They were identified based on species-specific morphological characters on permanent slides. Taxonomically important traits were studied in detail and measured under a microscope linked to a computer equipped with image analysis software (Olympus analySISdocu) and their measurements were taken by the scheme of Mas-Coma and Galan-Puchades (1991). The present descriptions are based on evaluation of tapeworm specimens collected from 15 individuals of $S$. rusticola. Measurements are in micrometers $(\mu \mathrm{m})$, except where indicated.

\section{Results}

Fuhrmanolepis beskydensis n.sp.

Type-hosts: Scolopax rusticola L.

Type-locality: Cigelka (Bardejov district)

Site of infection: Small intestine

Prevalence: Less frequent (number of specimens not counted due to the missing scolices hooks and other taxonomically significant features). Identified $2 / 15$, i.e. $13.3 \%$ of hosts

Material studied: Holotype No. 201/61b; Paratypes: 202/61š, 201/61e

Type material deposited in the Helminthological collection 

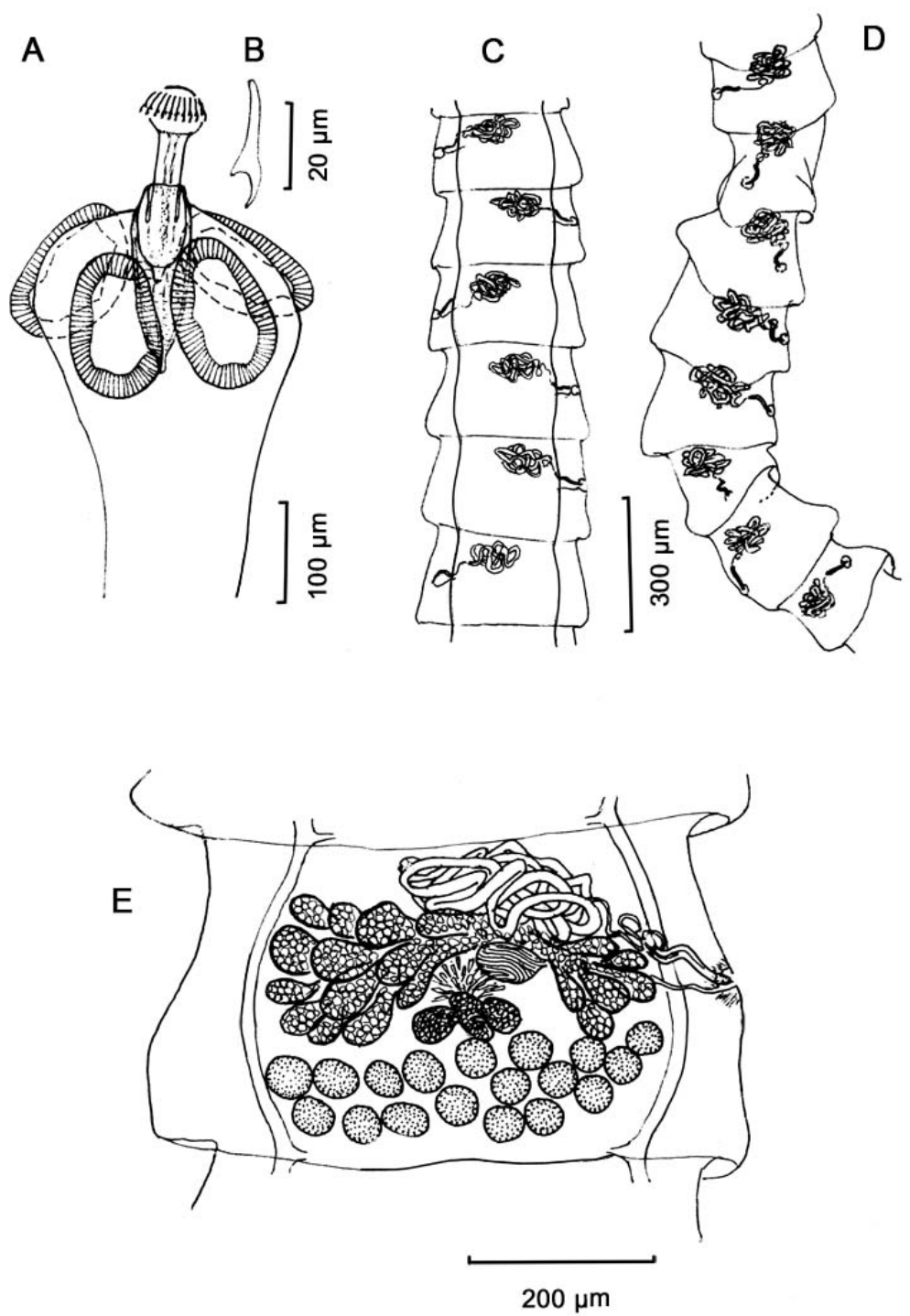

Fig. 1. Fuhrmanolepis beskydensis n.sp.

A-scolex; B-rostelum hook (holotype); C-strobilla proglottides with alternating genital pores (holotype); D-strobila proglottids, visible 'shifting' of pores , combined with their alternating within two last proglottides (paratype); E-hermaphroditic proglottis (holotype)

at the Parasitological Institute SAS, Hlinkova 3, 04001 Košice, Slovak Republic and in the Helminthological collection of the East Slovak Museum, Košice

Etymology: Specific name of the cestode has derived from the name of Nízke Beskydy mountain range in the northern Slovak borderland, where its type locality is situated.

Mature strobila $70.5-86$ x $0.718-0.975 \mathrm{~mm}$. Scolex 290 - 359 in diameter (Fig.1A). Suckers $140-180 \times 109-$ 154 , unarmed. Rostellar pouch extending to posterior margin of suckers. Rostellum 117 × 28 - 30. Apical disk 55 wide, armed with 21"diorchid" (wrench-shaped) hooks in a single row (Fig.1B). Hooks $28-30$ long. Blade $7-8$, base $22-24$. Width of hook 7. Segments usually wider than longer. Premature proglottides first develop primordia of male genital organs. Then they differentiate into $18-25$ testicules and irregularly alternating openings of genital pores (Fig. 1C), often situated slightly sublaterally. Abnormal shifting of genital openings through median part of $1-4$ segments to opposite lateral margins (Fig.1D; 2 A, B) was observed in holotype in four cases and in paratype in seven cases. Second paratype is juvenile. The segment containing shifting of genital porus near vitelarium, or posteriorly, usually narrowed. Sometimes deformed - as if his caudal half were formed from up to three connate halves of the segments with separated margins. ( Fig. 1D second segments and $2 \mathrm{~B}$ ). The genital organs in those segments are often grouped together and therefore in the total preparations they form dark, hardly differentiable aggregations of various structures. Osmoregulatory canals in these segments are missing. Despite this fact it seems that some organs and structure "rotate" without apparent 
A

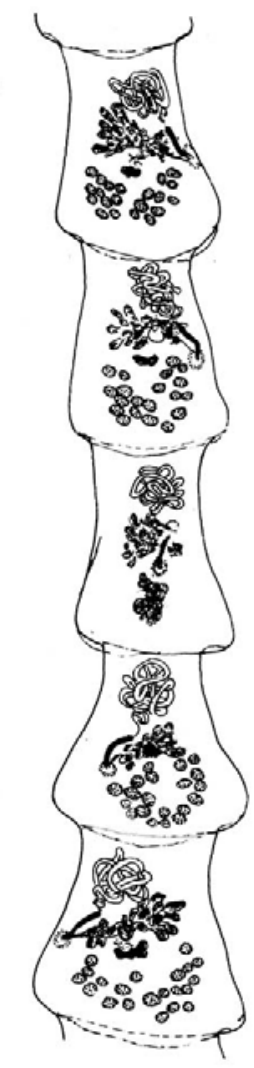

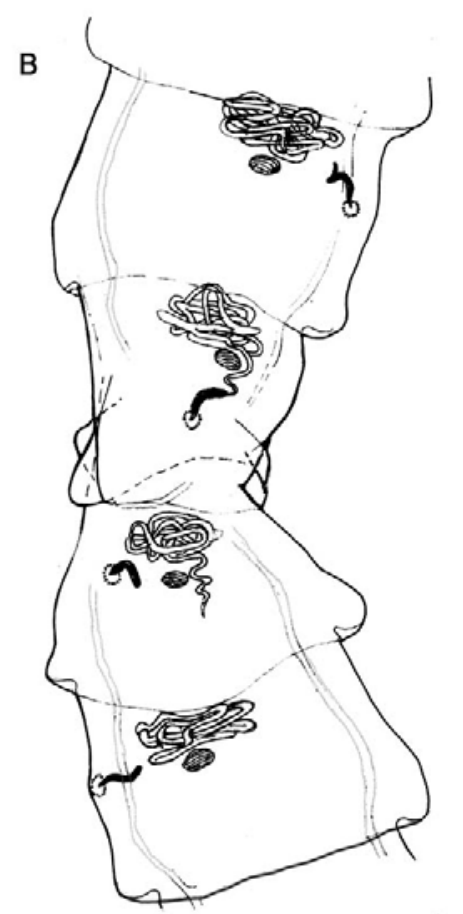

$300 \mu \mathrm{m}$

Fig. 2. Fuhrmanolepis beskydensis n.sp

A-shifting of genital pores within strobila margins; B-shifting of genital pores with narrowed and deformed postmature proglottid (holotype)

rotation of external strobila. In other cases, neither narrowing of segments nor their deformations in site of shifting are apparently visible (Fig. 1D-sixth segment; 2A; 4). After irregular alternating or shifting of genital pores, in strobila there is a row of segments (6-25 or more) with unilateral genital openings. In one case we observed in paratype 54 segments with unilateral openings. In hermaphroditic segment $385 \times 715$ (Fig.1E), testicules are 39 -62 in average, located in medium area of the segments between osmoregulatory canals posterior to ovarium and vittelarium. Loops of vas deferens in anterior part of segments. Distinctively developed cirrus sac (CS) $115-135 \mathrm{x}$ $7-12$, more or less of undulate shape. (Fig. 3B). Depending on a degree of undulation, CS may overlap poral osmoregulatory canals. In mature proglottides CS indistinct, thin-walled, with $1-2$ coils of internal vas deferens. It opens into small genital atrium in central, sometimes 'caudal' third of the segment margin, surrounded by relatively strong muscles. Evaginated, finely spinned cirrus slightly conical, protruding to 26 , at base $6-11$ in diameter. Indistinct vagina with less distinct preatrial vaginal sphincter (?) posteriorly to CS. Lobular two-winged ovary in aforementioned segment $385 \times 715$ has 444 in the longer diameter in the anterior part of the segment. (Fig. 1E). Receptaculum seminis and Mehlis's gland at ovarian isthmus. Vitelarium lobular, transversely elongated, 130 in diameter, posterior to ovary.

In postmature proglottides, net-like uterus develops (Fig. $3 \mathrm{~A})$ while ovarium and vitellarium degenerate. Testes visible for a long time. Periodically appearing in gravid proglottides. Loops of vas deferens very distinct also in these segments.

Reticulated uterus also retained in the segments with eggs filing almost whole space. Eggs round to oval, without filaments. Native $69-78 \times 54-57$. External envelope in permanent slides unclear, 35-42 x 34-36. Embryophore 21 - 33 in diameter, surface seeded with minute spines. Embryonal hooks $9-11$ long ( Fig. 3L.)

Holotype: 70.5 x $0.975 \mathrm{~mm}$. Scolex 290 in diameter, suckers $140-164 \times 109-117$. Twenty-one rostellar hooks 28 -29 long. Testicles $18-25$ in number. Cirrus sac $115-$ $131 \times 7-12$, cirrus slightly conical up to 24 long; at proximal parts $8-11$ wide. Ovary lobular. Uterus reticulate. Spinned embryophore 29 - 33. Embryonal hooks $9-$ $11 \mu \mathrm{m}$.

\section{Discussion}

A) Differential diagnosis

According to the way of genital pore openings, $F$. beskydensis n.sp. is the most similar to $F$. schikhobalovae (Krotov, 1951). New species differs in: a) a number of 21 rostellar hooks in comparison to 16 in F. schikhobalovae; b) shape of hooks (cfr. Fig. 3D; 3E); c) a greater number of testicles $18-25$ in comparison to $8-12$ in F. schikhobalovae; d) width of burs cirri $7-12 \mu \mathrm{m}$ in diameter, in comparison to $18 \mu \mathrm{m}$ in $F$. schikhobalovae. According to Krotov (1951), bursa cirri is very thin, extending behind poral excretory canals and without visible margins turning to vas deferens, $6 \mu \mathrm{m}$ (?) wide. e) Shape and jagged structure of vitellarium in contrast to round one in $F$. schikhobalovae; f) reticulated uterus (Fig.3A) as against horseshoe-shaped uterus in F. schikhobalovae (Fig. 3C); g) irregularly alternating genital pores in combination to multiple shifting of pores within lateral margins of strobila through $1-4$ segments (Fig. 1D., 2A, B). In F. schikhobalovae this is known as one-of transition of genital pores from one segment's margin to another within 12 segments. Krotov (1951) considers this number to be a species-specific. Voge's findings (1952a, 1952b) could be mentioned here as they demonstrated that the intraspecific variability including the frequency of some types of structural abnormalities of a species must also be considered a typical characteristic of the species in question.

Bona (1994a) considers mentioned shifting in the species of the genus Diagonaliporus Krotov, 1951 to be a rotation of a strobila and not a shifting of pores, as proved by the spiral course of the longitudal musculature and osmoregulatory canals. In $F$. beskydensis, these structures are not visible in the parts where the shifting takes place. However, there is more to it than meets the eye. Had it been just the case of strobila rotation, the sublateraly located genital pores would have then gradually transited (altogether by $180^{\circ}$ ), e.g. from the top side of strobila to the bottom one. 


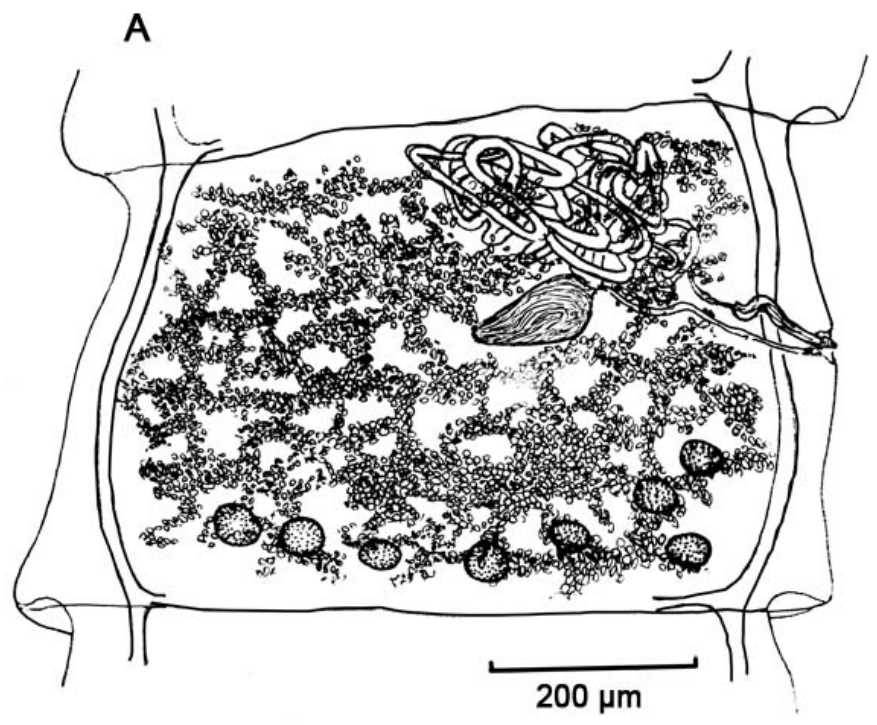

B

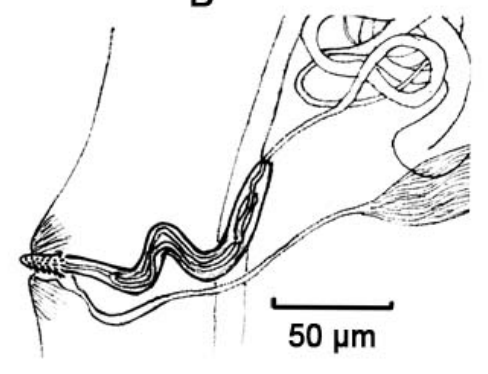

$\sqrt{D}$

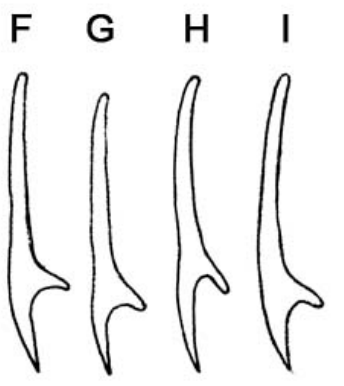

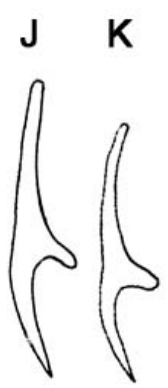

C

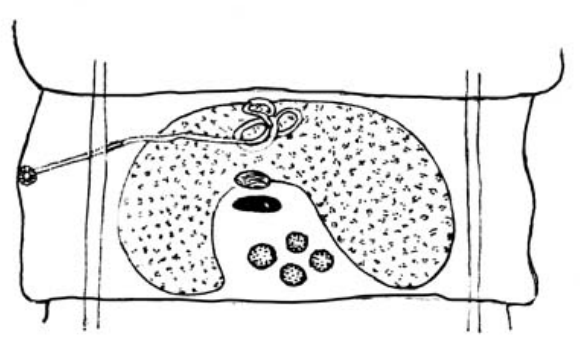

$\mathrm{L}$

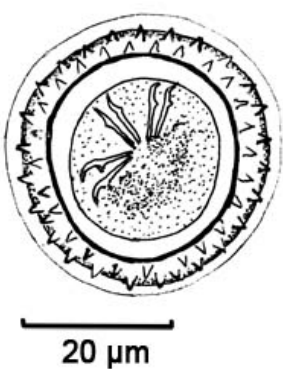

Fig. 3. Fuhrmanolepis spp.

A, B - F. beskydensis n.sp. A-postmature proglottis; B-cirrus sac; C-Fuhrmanolepis schikhobalovae - postmature proglottis with horse-shaped uterus (according to Krotov, 1951); D-K- hooks of compared dilepidids, lenght 28-34 $\mu \mathrm{m}$ according to various authors; D-Fuhrmanolepis beskydensis $\mathrm{n}$.sp.;

E-Fuhrmanolepis schikhobalovae (according to Krotov 1951); F - I - Fuhrmanolepis scolopacina, (F,G- our observations;) H- according to Spasskaya and Spassky, 1978); I- Choanotaenia cayennenis (Fuhrmann, 1907) var. scolopacis (according to Joyeux and Baer, 1939); J, K- Taenia embryo, hooks lenght 29-34 $\mu \mathrm{m}$; (according to Krabbe, 1869) L-Fuhrmanolepis beskydensis $\mathrm{n} . \mathrm{sp}$. egg.

In the given example (Fig. 2A; 2B) the pores are shifting only from the left margin of the segments through the median area of proglottis towards the right margin. In addition to it, it is known that some organs "follow" the opening of genital ducts in the segments even in the case of regular or irregular alternating. It is for instance the case of the ovary, where the poral wing is often less developed than aporal ones (Fig. 1E). Mechanism of this "rotation" is probably built into the genetic code of relevant taxon.
So far, no consensus has been reached among experts on a national level on either shifting or strobila rotation in $F$. beskydensis n.sp. Nevertheless it can be regarded as abnormality ad hoc without taxonomic implication. The authors are planning to study the subject by its more thorough observation. 8.) Distribution and occurrence. F. schikhobalovae was described in S. rusticola in the island of Sakhalin.

Comparing the number, measurements and shape of the 
hooks, F. beskydensis n.sp. is closely related to F. scolopacina (López-Neyra, 1944) (Fig. 3F-I). They differ in: a) measurements of strobilla $70.5-86 \mathrm{~mm}$ in contrast to $10-$ $22 \mathrm{~mm}$ in F. scolopacina; b) width of bursa cirri $7-12 \mu \mathrm{m}$ in $F$. beskydensis n.sp. in comparison to $20-33 \mu \mathrm{m}$ in $F$. scolopacina; c) maximum cirrus width $6-11 \mu \mathrm{m}$ in contrast to $15-16$ in F. scolopacina; d) distinct and compact knot of loops of vas deferens in contrast to loosely coupled loops in F. scolopacina; e) Reticulated uterus in comparison to sacciform uterus with septa in $F$. scolopacina sensu Spasskaya and Spassky (1978); or labyrynthine in Ovosculpta scolopacis (Joyeux and Baer, 1939) sensu Bona (1994a). Spasskaya and Spassky (1.c.) consider both forms (sub. e) to be synonyms of $F$. scolopacina (LópezNeyra, 1944); f) alternating genital pores. In F. scolopacina they alternate irregularly by $1-2$ segments.

In one particular strobila in F. scolopacina we observed shifting of genital pores through 2 segments on a ventral side of strobila. The segments margins are neither deformed nor narrowed (Fig. 4).

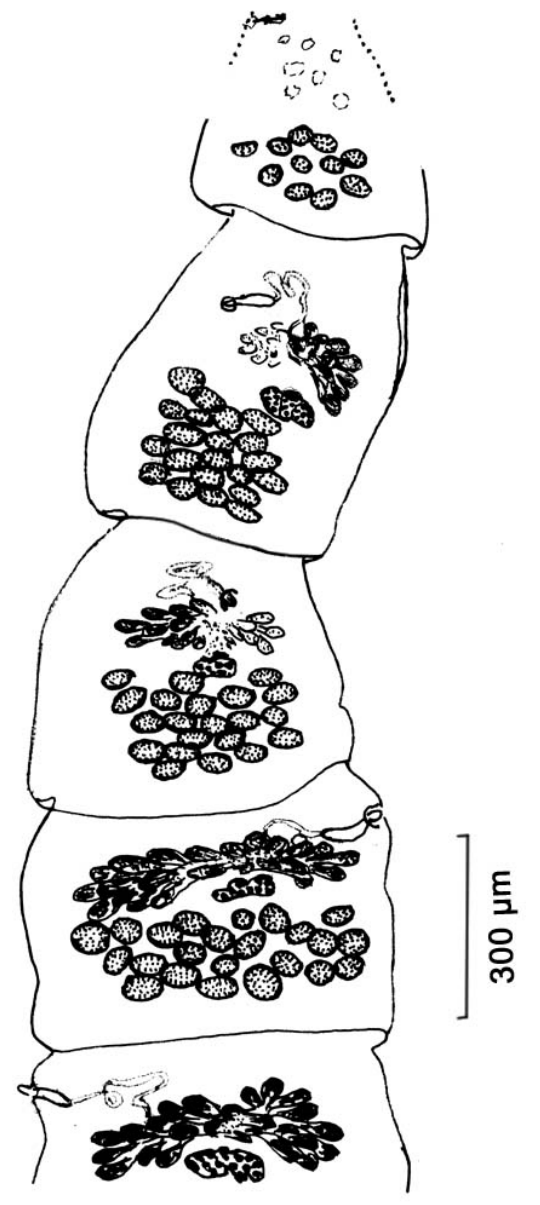

Fig. 4. Fuhrmanolepis scolopacina (López-Neyra, 1944) strobila withou scolex with incompletely developed eggs, app. $11 \mathrm{~mm}$ long

shifting of genital pores. Osmoregulatory canals invisible.

F. beskydensis n.sp. differs from insufficiently described taxon Taenia ebmryo Krabbe, 1869, in: a) number of hooks 21 in contrast to $14-16$ in T. embryo; b) shape of the hooks. In the new species, the hooks have relatively longer handle and shorter blade than the hooks in T. embryo (Figs.3 J, K); c) width of bursa cirri in the new species is $7-12$ wide, in Choanotaenia embryo (Krabbe, 1869) 42 - 52; d) shorter cirrus. In $F$. beskydensis it is protruded at 26, in Ch. embryo (Krabbe, 1869) 42 and other features (sensu Lopez-Neyra, 1944). Spasskaya and Spassky (1978) classified Ch. embryo (Krabbe, 1869) into the genus Polycercus Villot, 1883.

With long unilateral series between alternating of genital pores the new species is similar to Ethiopotaenia trachyphonoides Metrick, 1961. This taxon does not posses apical apparatus (Bona, 1994a), as the new species does.

Sandeman (1959) refers to strobilae with unilateral genital pores and those with alternating pores belonging to the only species of Dilepis africana. It is also possible to presume such similarity in $F$. beskydensis n.sp., as in the strobila section, $19.8 \mathrm{~mm}$ long, 54 segment with unilateral genital pores were observed. Therefore the new species was compared to the taxons with unilateral pores. $F$. beskydensis was similar only with $F$. schiklobalovae, classified into the genera with unilateral pores. Schmidt (1986) classifies this species in to the genus Valipora Linton, 1927, and Bona (1994a) into the genus Trichocephaloidis Sinitzin, 1896. According to Krabbe (1882), unilateral pores are also visible in $50 \mathrm{~mm}$ long Taenia bacilligera Krabbe, 1869. F. beskydensis n.sp. differs from theses species in a single crown of 21 hooks in contrast to double crown of 20 hooks $21-23$, or $18-25$ in T. bacilligera. Other taxonomically significant features are not known from the original descriptions of Krabbe (1869; 1882). Other dilepidid species with unilateral pores possess different combination of taxonomically significant features than those in F. beskydensis n.sp.

B) Nomenclature and taxonomy of the genus Fuhrmanolepis Spassky et Spasskaja, 1965

Problems concerning the identification of new species with regards to genera requires a brief commentary on the genesis of the genus Fuhrmanolepis and Fuhrmannolepis to clarify the opinion resulting in such interpretation of $F$. beskydensis n.sp.

The diagnosis of the genus Fuhrmanolepis was formulated by Spassky and Poznakomkin (1966) on the basis of material from Calidris alpina from Anadyrja (the former U.S.S.R.). Spasskaya and Spasky (1978) omitted numbers of hooks in diagnosis and included 10 species into this genus, resulting in $F$. slesvicensis comprising two taxons: $F$. slesvicencis sensu Clerc, 1903 and F. slesvicencis (Krabbe, 1882). Schmidt (l.c.) synonymized the genus Fuhrmanolepis Spassky et Jurpalova, 1967 with the genus Dilepis Weinland, 1858. Bona (1994a) has not only amended the name Fuhrmanolepis for Fuhrmannolepis Spassky et Spasskaya, 1965 but also essentially modified the diagnosis of this genus. He was under the impression that Spassky and Poznakomkin (1966) probably described a species different from decacantha Fuhrmann, 1913. Diagnosis of Fuhrmannolepis Spassky et Spasskaja, 1965 sensu Bona (1994a) refers to Fuhrmann's type material. 
According to Bona (1994a), several other species from the original genus Fuhrmanolepis as conceived by Spassky and Spasskaya (1965) contain species belonging to the other genera, including Sacciuterina. These are Ovosculpta Bona, 1994; Trichocephaloidis Sinitzin, 1896 (syn. Diagonaliporus, Krotov, 1951); and perhaps other genera, which are not listed there. Unless synonymia of the genus Fuhrmanolepis Spasky et Spasskaya, 1965 with other genus is provided or unless another nomenclature act carried out, the taxonomical status of the genus Fuhrmanolepis (1.c.) remains unclear.

According to Articles 32.sub; 32.2; 32.5 and 56.sub 56.2 of the International Code of Zoological Nomenclature (ICZN1999) and examination of rules concerning the 'justified and unjustified' emendation, cf. 33.2.2 and 33.2.3. the studied dilepidids comprises following genera:

1.) Fuhrmanolepis ${ }^{l}$ Spassky et Spasskya, 1965 sensu Spassky and Poznakomkin (1966), resp. Spasskaya and Spassky (1978). Besides other features, it is characterised as having pinhead-like apical disc (without two lobes) armed with a single crown of wrench-shaped hooks (1030) Genital ducts between osmoregulatory canals. Embryophore in typical species spiny or granular. (type-species: Fuhrmanolepis decacantha Fuhrmann, 1913). The original description of Choanotaenia decacantha offers following comments on rostellum "Das Rostellum ist offenbar sehr lang mit knopfförmiger Anschwellung am Ende und trägt nur 10 Haken von 0.0198-0.0216 mm Länge" (Fuhrmann, 1913). Concerning the name Fuhrmann, the emendation of the Fuhrmanolepis to Fuhrmannolepis seems to be justified. As it follows from particular paragraph of the Article 32.5.1, this is not the case of ".. an inadverted error - such as lapsus calami or copyist's or printer's error..." This is well documented in the papers published in Russian language, with Fuhrmanolepis written not once only with a single ' $\mathrm{n}$ ', while in brackets Fuhrmann is listed with double 'nn' (Skryabin \& Mathevossian, 1945; Spassky, 1951, 1968; Spassky \& Poznakomkin, 1966; Spasskaya \& Spassky 1978; Schmidt 1986) and others.

Besides the name Fuhrmanolepis, various published sources also cite the genus Fuhrmanacanthus Spassky, 1966 with a single ' $\mathrm{n}$ ' (Schmidt, 1986; Czaplinsky \& Vaucher, 1986; 1994; Mas-Coma \& Galan-Pachades, 1991 and others). Though it is necessary to point out that the name Fuhrman with a single ' $n$ ' is often stated in the various literature sources, including the Internet.

2.) Emended Fuhrmannolepis Spassky et Spasskaya, 1965 sensu Bona (1994a) syn. Taeniarhynchaena Burt, 1983. We are convinced that this taxon emended by Bona (1.c.) can be considered to be a separate genus. Characterised -

\footnotetext{
${ }^{1}$ Only the generic names are taken into the consideration in this particular case. Names of the authors that are nomenclatorial part of the taxons' scientific name are listed here exactly as presented by the Russian authors. Their references in the text are based solely upon assessment of a translator.
}

besides other- by wide, slightly bilobbed apical disc, a single crown of wrench shaped hooks (10), five on each rostellar lobe, genital ducts between osmoregulatory canals. (In syn. Taeniarhynchaena Burt, 1983 [Burt 1.c.] refers to genital ducts being dorsal to longitudinal excretory vessels). Vagina with pre-atrial sphincter. Uterus coarse-meshed reticulum. Embryophore smooth. Type species: F. decacantha (Fuhrmann, 1913) sensu Bona (1994a).

Aforementioned Choanotaenia decacantha Fuhrmann, 1913 was described by Furhmann (1913) according to a single tapeworm specimen. Wirt, Tringa alpina; Fundort: Takern 5/9 09 (No. 145). It seems that No. 145 is actually a number of a test tube (cf. Fuhrmann, 1908a, 1908b, 1909). Other work, while describing new species, omit even this No. Fuhrmann et Baer (1943).

According to our data, Fuhrmann's material of Ch. decacantha comprises specimens and segments of several strobila and therefore it is unclear whether the type material in that particular test tube is indeed morphologically homogenous or comprising tapeworms with scolex and apical disc not being divided. To prevent any dubiousness, it is necessary - besides the type species illustration (lectotype ?) of $F$. decacantha (sensu Bona 1994a:518) to redescribe the whole Fuhrmann's material of Ch. decacantha and to publish the numbers of type specimens, conforming to the rules of the ICZN (Articles 73-75). In such questionable matter, when it seems that $F$. decacantha had been wrongly identified (Article 70a.) of the ICZN- 1959), the case should be submitted to the Commission of ICZN, which is to decide on such matter (Article 79). The fourth Edition of the ICZN (1999-2000) requires the same procedure (cfr. Article 70.2), moreover when in this case the diagnosis of the genus has also been changed.

3.) Aforementioned creation of the genus Fuhrmannolepis sensu Bona (1994a) has also called for description of the genus Ovosculpta Bona, 1994. Its diagnosis include, besides other, a single crown of numerous (18-22), wrenchshaped hooks. Proglottis sides often deformed. Genital ducts between osmoregulatory canals. Vagina in front of entering atrium with pre-atrial sphincter. Uterus labyrinthine. Embryophore sculptured. Type species: O. scolopacis (Joyeux et Baer, 1939) Bona, 1994.

Diagnosis of the Ovosculpta is so similar to that of the genus Fuhrmanolepis sensu Spasskaya et Spassky (1978) that Bona's genus could be considered as its part, as evidenced by its type species $O$. scolopacis, believed to be a synonym of $F$. scolopacina (López-Neyra, 1944) Spasskaja et Schumilo, 1971 (ex Spaskaya et Spassky 1.c.). However, it is unclear, where to include according to Bona (1994a) e.g. dilepidids Fuhrmanolepis with 10 wrench-shaped hooks in a single circle at compact rostellar apical disc (without two lobes). Sacciuterina Mathevossian, 1963 would probably not be the case here, as it has according to Bona (1.c.) porosoid hooks.

In order to better evaluate mentioned data and opinions, a register of all the species comprising the genera of the Bona's system would be very useful. These registers are 
offering valuable information on views of revising author(s) on volume and boundaries of the genera (Mayer, 1964, 1969), on validity and synonymity of the species and other data which are also important when selecting a system. Unfortunately, the 'Keys to Cestode Parasites of vertebrates' (Eds. Khalil et al., 1994) misses these data that have considerably complicated identification of dilepidid species according to the aforementioned system. The problems occur in particular when describing new species and their differentiation from close taxons published often with a short description of few traditional characters (cfr. Bona, 1994b:206).

Other authors has also encountered similar problems while placing species into the genus Fuhrmannolepis, e.g. in Fauna Europea $^{2}$ (April 10, 2007; last update 2005), the examined genus comprises species published without the authors of their scientific name of and the year of the first publication. Probably it concerns following species: $F$. arctica (Baylis, 1919); F. averini Spassky et Jurpalova, 1967; F. birostrata sensu Belogurov et Zueva, 1968 (nec ? sp. birostrata Clerc, 1906), F. decacantha (Fuhrmann, 1913) - it is dubious whether it is the case of sp. Fuhrmanolepis decacantha (Fuhrmann, 1913) sensu Spassky et Poznakomin (1906), or sp. Fuhrmannolepis decacantha (Fuhrmann, 1913) sensu Bona (1994); F. rotunda (Clerc, 1913), F. scolopacina (López-Neyra, 1944), F. slesvicensis (Krabbe, 1882). These taxons have from 10 up to 30 hooks in a single crown with compact disc-shaped apex or slightly bilobed apical disc with five hooks at each rostellar lobe. They also include the species with unilateral or alternating genital pores; with sacciform, reticulate or labyrinthine uterus; with smooth or sculptured embryophore. The genus with such a vast species spectrum should have had a wider diagnosis of Fuhrmannolepis than that formulated by Bona (1994a).

In this paper we have decided to accept ad hoc the system of Spasskaya and Spassky (1978) owing to the fact, that it meets the above-mentioned criterions. However, the new findings and observations have resulted in necessity to complete several data on dilepidid species of Charadriformes and to bring into accord the classification with the ICZN and some other taxonomic categories of dilepidids. Such task exceeds the scope of this paper, which is only a part of a faunistic survey of Slovakia as papers by Dudiňák \& Špakulová (2005) and Hanzelová et al. (2007).

\section{Acknowledgements}

The authors are grateful to Dr. B.B. Georgiev from the Central Laboratory of General Ecology, Bulgarian Academy of Sciences, Sofia, Bulgaria for his valuable comments on recent systematics of some genera of Dilepididae, to Dr. A.K. Galkin from the Institute of Zoology, St. Peter-

\footnotetext{
${ }^{2}$ The species list of the genus Fuhrmannolepis in the Fauna Europea has been created based on the data on taxons of aforementioned genus in Europe provided by various authors. (Špakulová, personnal communication).
}

sburg, Russia and to Prof. C. Vaucher for kindly providing us with the rare and old literature. Last but not least we thank Dr. M. Špakulová and Dr. V. Hanzelová for valuable advice and kind help with obtaining data on Funrmann's material. The study was supported by the grant Agency of the Slovak Republic VEGA, project No. 2/7192/27 and the European Commission Research Infrastructure Action via the SYNTHESIS project No. DK-TAF-2354.

\section{References}

Belogurov, O. I., Zueva, L. S. (1968): Two new cestode species of shorebirds from Far East. Soob. Dalnevost. Fil V. L. Komarova ANSSR, 26:11 - 17 (In Russian)

BonA, F. V. (1994a): Family Dilepididae Raillet \& Henry, 1909. In KhaliL, L. F., Jones, A., BRAY, R. A. (Eds): Keys to the cestode parasites of vertebrates. $\mathrm{CAB}$ International, Wallingford, 1994

BONA, F. V. (1994b): Three new species and genera of Dilepididae (Cestoda, Cyclophyllidea) from neotropical Picidae (Aves). Rev. Suisse Zool., 101:195 - 213

BURT, D. R. (1983): Taeniarhynchaena micropalamae gen. et sp.n. (Cestoda, Dilepididae) from the stilt sandpiper Micropalama himantopus (Bonaparte, 1826). J. Parasitol., 69: $750-753$

Clerc, W. (1906): Notes sur les cestodes d'oiseaux de l'Oural. Zbl. Bakt. Parasitenk. Infektionskrank. Hyg. 42: $713-730$

CZAPlinski, B., VAuCHER, C. (1986): Parasitic helminthes of Paraguay. 8. Redescriptions of Fuhrmanacanthus propeteres (Fuhrmann, 1907) Spassky, 1966 (syn. Lateriporus biuterinus Fuhrmann, 1908) (Cestoda, Hymenolepididae) and remarks on Fuhrmanacanthus Spassky, 1966 and Hematolepis Spassky, 1962 genera. Syst. Parasitol., 8: 83 - 90

CZAPlinsky, B., VAuCher, C. (1994): Family Hymenolepididae Ariola, 1889. In: KHALIL, L. F., JONES, A., BRAY, R. A. (Eds): Keys to the cestode parasites of vertebrates. CAB International, Wallingford, 1994

DUDIŇÁK, V., ŠPAKULOVÁ, M. (2005): A survey of helminth species originally described from the territory of Slovakia supplemented by a list of the type material deposited in the East-Slovakian Museum (Východoslovenské museum) in Košice. Helminthologia, 42: 233 - 245

FERIANC, O. (1977): Birds of Slovakia. I. Publ. House VEDA, Bratislava (In Slovak)

GIBSON, D. (Ed) (2007): Fauna Europaea Web Service (2004) Fauna Europaea version 1.3, Retrieved October 25, 2007 from http://www.faunaeur.org

FuHRmann, O. (1908a): Nouveaux tenias d'oiseaux. Rev. Suisse Zool. 16: 27 - 73

Funrmann, O. (1908b): Das genus Anonchota und Biuterina. Zbl. Bakt. Parasitenk. Infektionskrank. Hyg. 46: $622-631$

Fuhrmann, O. (1909): Das Genus Annonchotaenia und Biuterina. II. Das Genus Biuterina Fuhrmann. Zbl. Bakt. Parasitenk. Infektionskrank. Hyg.I. Abt, 48: 412 - 428

FUHRMANN, O. (1913): Nordische Vogenlcestoden aus 
dem Museum von Goteborg. Medd. Gotebotgs Musei zool Adelning, Vol. 1: 41

Funrmann, O. et BAER, J. G. (1943): Cestodes. Bull de la Soc. Nauchat. Des Sciencies Nat. 68: $113-140$

HanzelovÁ, V., Macko, J. K., MackovÁ, A. (2007): Anomotaenia barusi sp. nov. and A. alata (Cestoda, Dilepididae) from Charadrins dubius (Aves, Charadriiformes) in Slovakia, with comments on related specias. Acta Parasitol., 24 - 30: 1230 - 2821

JoyeuX, CH. et BAER, J. G. (1939) Sur quelques cestodes des Charadriiformes. Bull. Soc. Zool. France, Vol.64: 171 $-186$

Khalil, L. F., Jones, A., Bray, R. A. (1994) (Eds): Keys to the cestode parasites of vertebrates. $\mathrm{CAB}$ International, Wallingford

KrABBE, H. (1869): Bidrag til Kundskab om Fuglenes Baendelorme. Kgl. Dansk. Vidensk. Selsk. Skr., Naturv. og Math. Afd.8, Bind VI.:8: 249-363 (In Danish)

KRABBE, H. (1882): Nye Bidgar til Kundskab om Fuglene's Baendelorme. Kgl. Dansk Vidensk. Selks. Biol. skr., 6,1: 347 - 366. (In Danish)

Krotov, A. I. (1951) New cestodes of birds. Trudy GELAN, 5:130-137 (In Russian)

LÓPEZ-NEYRA, C. R. (1944): Compendio de helminthologia Iberica (Continuacion) Pt.II, Cap.II. (Family Dilepididae Fuhrmann). Rev. Iber. Parasitol., 4: $207-241$

Mas-Coma, S., Galan-Puchades, M. T. (1991): A methodology for the morphoanatomic and systematic study of the species of the family Hymenolepididae Raillet et Henry, 1909 (Cestoda: Cyclophillidea). Res. Rev. Parasitol., 51: $139-173$

MAYER, E. (1964): Sytematics and the origin of species from the viewpoint of a zoologist. Dover Publications Inc., New York

MAYER, E. (1969): Principles of systematic zoology. McGraw - Hill Book, New York-Toronto-London

RYŠAVÝ, B., FARKAŠ, J. (1982): Occurrence of tapeworms in woodcock in Slovakia. Folia Veterinaria, 12: $261-268$ (In Slovak)
SAnDEMAN, I.M. (1959) A Contribution to the revision of the Dilepid tapeworms from Charadriiformes. Preliminary note. Zool. Anz., 163: 278 - 288

SCHMIDT, G. D. (1986): CRC Handbook of tapeworm identification. CRC Press Inc., Boca Raton, Florida

SKRYABIN, K. I., MATHEVOSSIAN, E. M. (1945): Cestodes hymenolepidids - of domestic and game birds. Seljkhozgiz, Moscow: pp. 486.

Spasskaya, L. P., Spassky, A. A (1978): Cestodes of Birds in the USSR. Dilepididae of limnophilous birds. Publishing House Nauka, Moscow (In Russian)

SPASSKY, A. A. (1951): Anoplocephaline cestodes of domestic and free-living animals. In SKRYABIN, K. I. (Ed.): Essentials of Cestodology. Publishing House Nauka, Moscow, 1, 735p. (In Russian)

SPASSKY, A. A. (1968): Comparative morphological analyses of dilepidids of Anomotaenia genus ( Cestoda: Cyclophyllidea). The Parasites of Animals and Plants. Publishing House Nauka, Moscow, IV: 23 - 52 (In Russian)

Spassky, A. A. et Jurpalova, N. M. (1967): Fuhrmanolepis averini n.sp.- a new dilepidid species of plovers of Chukotka. Publishing House of AS MSSR, 1: 17 - 22 (In Russian)

Spassky, A. A. et Poznakomkin, S. D. (1966): The genus Fuhrmanolepis (Cestoda: Dilepididae). Parasites of animals and plants Kishinev, Kartya Moldovenyaske, 2: 87 - 97 (In Russian)

SpASSKY, A. A. et SpASsKayA, L. P. (1965): Revision of the genus Paricterotaenia (Cestoda: Dilepididae). Parasites of animals and plants Kishinev, Kartya Moldovenyaske 1: 84 - 104 (In Russian)

VoGE, M. (1952a): Variation in some unarmed Hymenolepididae (Cestoda) from rodents. University of California, Publ. Zool., 57: 1 - 52

VoGe, M. (1952b): Variability of Hymenolepis diminuta in the laboratory rat and in the ground squirrel Citellus leurucus. J. Parasitol., 28: 454 - 456 